\title{
Instagram and Millennial Generation: \#Explorebanyuwangi Analysis
}

\author{
Heidy Arviani $^{1}$, Ghassani Shabrina Prasetyo ${ }^{2}$, Vicky Virgiawan Walgunadi ${ }^{3}$ \\ ${ }^{1}$ Department of Communication Sciences, UPN "Veteran" Jawa Timur \\ ${ }^{2}$ Department of Communication Sciences, UPN "Veteran" Jawa Timur \\ ${ }^{3}$ Department of Communication Sciences, UPN "Veteran" Jawa Timur \\ Corresponding Author’s Email: heidy_arviani.ilkom@upnjatim.ac.id
}

\begin{abstract}
One of the unique things of the millennial generation, they allocate more income for travel rather than buying houses, branded goods (fashion), gadgets. The size of the income does not put the desire of millennials to travel any less. e-Promotion is promotional activities through the internet or especially social media that will influence the purchase decision of products and services. The cost needed to carry out advertisements and promotions on the internet and social media is very affordable. This effectiveness is certainly influenced by travel agents from small to large scale to do promotions. Instagram is used as a media platform that provides education and information on many things, including traveling. Instagram features visualizations of various tourist destinations. Millennials and Banyuwangi can collaborate to maximize this potential through the \#explorebanyuwangi tagline on Instagram. The author then purpose formulation of the problem; (1) How about \#explorebanyuwangi content on Instagram? (2) What are the millennial generation's preferences for traveling info on \#explorebanyuwangi? There are three data collection methods used by researchers (1) Online Survey, (2) Social media observation, literature review \& literature study. The results of the study showed 364 thousand hashtag \#explorebanyuwangi in the form of photos and videos. Millennials who see \#explorebanyuwangi post-claim want (40.3\%) and eager (9.7\%) to visit Banyuwangi's natural attractions.
\end{abstract}

Keywords: e-Promotion, Instagram, millennial, \#explorebanyuwangi

\section{INTRODUCTION}

Sunrise of Java or commonly called Banyuwangi is one of the cities in East Java located at the easternmost tip of the island of Java. The northern boundary of Banyuwangi Regency is Situbondo Regency, the east is the Bali Strait, the south is the Indonesian Ocean, and the west is bordered by Jember and Bondowoso Regencies. According to the Banyuwangi Bappeda in 2013 , the area of Banyuwangi itself was $5,782.50 \mathrm{~km} 2$ which was divided into 24 sub-districts, 28 villages, and 189 villages (Bappeda, 2019).

There are several tours offered by Banyuwangi, among them are Pulau Merah Beach, Ijen Crater, Alas Purwo National Park, Pelengkung Beach / G-land, Kalibendo Waterfall, Baluran Nature Reserve, Wahana X-Badeng Adventure, Blue Bay Bay, etc. As one of the districts that have many tourist destination destinations that have the potential to be developed and disseminated, Banyuwangi certainly needs promotion encouragement through the millennial generation in e-Promotion strategies to strengthen identity and development for the target market needs of the general public.

According to Lysons, the millennial generation has different characteristics in each individual - depending on where he grew up, the economic strata, and social family. The 
millennial generation is also famous for very open communication that is very close and even fanatical about social media (Putra, Yanuar). Alvara Research Center (2014) says that millennial generation internet consumption is much higher than the age group above. This proves that the internet, especially social media is the world of the millennial generation (Juditha, 2019).

e-Promotion is promotional activities through the internet or especially social media that will influence the purchase decision of products and services. Media e-Promotion that is intensively carried out at this time in the millennial generation are Instagram, email, Facebook, and Twitter. With millennial generation segmentation that is closely related to the internet and social media, the e-Promotion strategy will produce targeted and effective promotions. In this strategy, millennials and Banyuwangi can collaborate to maximize the potential and capabilities that are packaged with the \#ExploreBanyuwangi tagline on social media. With hope, visitors get a top mindset about Banyuwangi Tourism.

Banyuwangi is a district that is now worth a visit, especially the millennials who currently have a high influence on technology and social media. Millennials are human groups that are closely related to technological developments. At present, the millennial generation is busy developing innovations to advance technology. So, they no longer compete between friends or neighbors, the millennial generation is struggling with world technology. Today, the millennial generation is playing an important role in the progress of the world through digital technology. This can be utilized in various fields, such as promotional activities in the exploration of the beauty of Banyuwangi Tourism Objects through e-promotion with the tagline \#ExploreBanyuwangi.

Various tours in Banyuwangi and the millennial generation can work together to present and present the latest ways to balance the progress of both. Related to this background, the researcher proposes the problem formulation in this research paper:

1. How about \#ExploreBanyuwangi content on Instagram?

2. What is the preference of the millennial generation for traveling info on \#explorebanyuwangi?

\section{LITERATURE REVIEW}

\section{Millennial Generation \& Travelling}

Millennials (also known as Generation Y) are the demographic group after Generation $\mathrm{X}(\mathrm{Gen}-\mathrm{X})$. There is no definite time limit for the beginning and end of this group, experts and researchers usually use the early 1980s as the beginning of the birth of this group and the mid1990s to early 2000s as the end of birth. Millennials in general, are children of the older Baby Boomers and Gen-X generations. Millennials are sometimes referred to as "Echo Boomers" because of the "boom" (large increase) of birth rates in the 1980s and 1990s.

There are many popular terms in the mention of this millennial generation; connected / digital generation or gen why that is synonymous with brave, innovative, creative, and modern characters. The most identical and closely related to this generation is the development of technology and telecommunications, which is characterized by the existence of social media. But other than that, there is one more thing that is an identifying characteristic of the millennials, namely the lifestyle of traveling. Of the many activities that can be used as a hobby, currently traveling is one of the activities that are in demand by many groups, especially the millennial generation (Tempo, 2017).

Lifestyle over time and changing generations will always develop, one example is traveling that becomes a lifestyle, especially in young children of the millennials. Jack S. Ezon 
(president of Ovation Vacations, and a member of the Travel \& Leisure Official Travel Advisory Board) explained that in general, the millennial generation saw traveling as a right and a need, so traveling was considered to be a way of life and part of their lives (Boston Globe, 2012). One of the unique things of the millennial generation is that it prefers to allocate income for a journey rather than having to buy a house, branded goods (fashion), gadgets. The size of the income does not break the desire of millennials to travel.

Based on www.phinemo.com, a survey conducted by Topdeck Travel to 31,000 people from 134 different countries, as many as 88 percents stated that they have traveled abroad three times a year and 94 percent are aged 18-30 years. Young people are said to be more interested in traveling abroad than older people. The UN even said that 20 percent of all world tourists are young people, the millennials.

\section{Adventure Tourism}

Traveling has become a global phenomenon, or more appropriately called a lifestyle in the current era. Adventure tourism also becomes the choice of the community especially young people as their traveling style. In ordinary traveling, maybe only travel that can be obtained. But in adventure tourism also includes outdoor activities and sports activities (Hudson, 2012: 203). There is no absolute definition that explains what the requirements are adventure tourism, making the context very broad. Even travelers traveling around an area are categorized as adventure tourism.

The many types of places and destinations that can become adventure tourism destinations, resulting in 3 classifications of adventure tourism, which are based on land, air, and water. Of course, the types of activities and activities that can be done when traveling will be different and have a plus value each. What makes the difference in adventure tourism is that it is based and is directly related to nature. Nature changes its condition all the time, every season. Many adventurous activities that are suitable and more optimally enjoyed at certain times or seasons, for example, water adventures such as snorkeling, rafting, which are suitable in summer (Swarbrooke, 2003: 167). Certainly making many travelers will be more challenged and excited in trying various adventure tourism destinations.

But not everyone is suitable and likes adventure tourism. Swarbrooke et al said that the lifestyle of each tourist will affect what kind of tourism trip they would like. In the context of adventure tourism, of course, travelers who like adventure and challenges, like nature and scenery, and strong physical activity, considering that adventure tourism contains a lot of activities and movements. The adventure traveler also has several 'types', namely those who travel occasionally only when they want it, there are also those who always do an adventure trip on each of their holidays. Currently, tourism adventures have begun to mushroom and become part of people's lifestyles, especially young people who are still full of enthusiasm and energy, in accordance with the characteristics of children in this era who are always full of curiosity, visiting adventure tourism destinations is also one of the destinations the object they enjoy.

\section{Instagram as Traveling Info Source}

Amid the development of social media today, one of the most popular is Instagram. The meaning of the first word is taken from the word 'instant' which is fast or easy, while the word 'gram' is taken from 'telegram' whose meaning is associated with the media of sending information very quickly (Instagram, 2016). In essence, Instagram is a social media that provides features for users to upload and share photos, videos, and Instagram stories to their 
followers. The sophistication of its features is very modern and virtual makes Instagram as the most popular social media, lined up with other media such as Youtube and Facebook. The Indonesian Internet Service Users Association (APJII) in 2017 revealed that Indonesia's internet use reached 143.26 million from 262 million people or as much as 54.68\%.

Young people or millennials who have a tendency to be in cyberspace are certain to have at least one personal Instagram account. But not only is it a medium for young people to show their existence, but Instagram is also increasingly widely used. The high number of users and the sophisticated Instagram feature make this social media utilized by various parties and interests such as being an official account of a brand, a trading account, a community account, a business account, and what is currently rife is a traveling account.

In this modern era, information search has rarely used guidebooks and maps since the internet and other media are internet-based. Of course, Instagram is also used as a media platform that provides education and information on many things, including traveling, especially in highlighting the visualization of various existing destinations. In addition to information and education, of course, there are also promotions. This is caused by the existence of a clear link between traveling and Instagram as a photo-sharing media. In addition to being proof of the traveling activity, photos have also become a medium for communicating the essence of the traveler (Carson, 2017:115).

Instagram is well known as a social media platform that is also a promotional platform, especially in the context of travel. According to Swarbrooke et al, the internet has resulted in a transformation of the marketing process in the field of travel, one of the reasons is the price needed to carry out advertisements and promotions on the internet and social media is very affordable, compared to printing brochures and pamphlets. This effectiveness is certainly very influential on travel agents from small to large scale to carry out promotions through Instagram (2003: 161). Therefore many Instagram-based accounts are found, which are also very useful for travelers to search for information such as destination choices and tourist tours.

\section{METHODOLOGY}

There are two data collection methods used by researchers, including:

1. Online Survey Method

Researchers distributed questionnaires online in the span of September 2019 to the millennial generation in the city of Surabaya. The research sample uses accidental sampling. Selected respondents must meet the following criteria: (1) aged 13-24 years; (2) Living in the city of Surabaya; (3) Agree to participate in surveys; (4) Has the capacity to answer questions. In total there are 184 people who are willing to fill out the survey.

2. Observation, Literature Review \& Literature Study carried out as secondary data and assist analysis. Observation is the collection of data or information that must be carried out by making observational efforts directly to the place to be investigated. Observations include observations on \#explorebanyuwangi Instagram, interviews, and analysis of Instagram post responses. 


\section{RESULTS AND DISCUSSION}

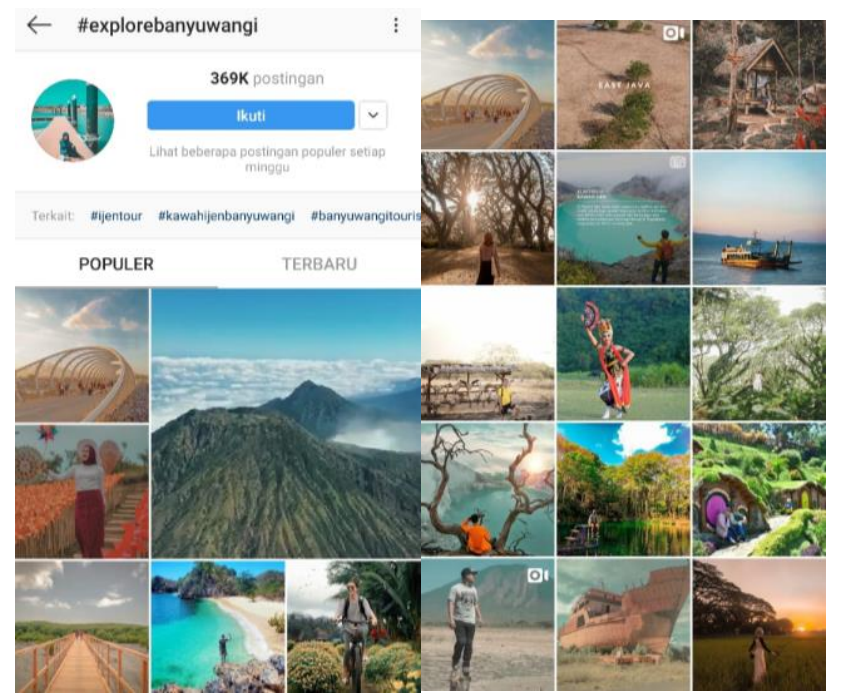

Picture 1. \#explorebanyuwangi as seen on Instagram

Banyuwangi is the easternmost district of Java island, which is the widest district in Java with an area of 5,800 KM2 directly bordering Situbondo Regency in the north, Bali Strait in the East, the Indian Ocean in the south and Jember Regency and Bondowoso Regency in the west. Many things from Banyuwangi that are interesting to discuss starting from the Ohing tribe which is a native tribe of Banyuwangi, in terms of the nature of Banyuwangi which is geographically located in natural and wild tourist areas like safaris in Africa, and its location close to the Indian Ocean makes Banyuwangi has beaches that are still clean and beautiful. Many tourists who come to Banyuwangi to enjoy its natural beauty, and do not forget to capture the moment in the form of photos and videos that will later be uploaded on social media, especially Instagram.

Currently, Instagram is a social media that is still widely used in Indonesia. Through Instagram, users can post photos and videos for their Instagram followers and other Instagram users to see. \#explorebanyuwangi on Instagram is a hashtag that has collected 364 thousand both in the form of photos and videos that have been posted by Instagram users by including \#explebebanyuwangi in their captions. There are 2 features on the \#explorebanyuwangi hashtag that are popular and the latest, where the popular feature is presenting the top photo photos with the most number of likes and comments, while the latest feature is presenting photos that have just been uploaded.

The main function of hashtag itself on Instagram is to group content and facilitate searching. In addition to grouping content and making it easier to search, the hashtag function on Instagram is also useful for branding and promotion needs. By making a special hashtag on each post, it will make a brand characteristic.

Content on \#explorebanyuwangi itself is more focused on the natural beauty of Banyuwangi, both the beaches, mountains, and plateaus, as well as the atmosphere of the city of Banyuwangi. But for the atmosphere of the city, it can still be said to be rare because Banyuwangi itself is more famous for its natural beauty, such as photos in Baluran National Park where the photos present a beautiful view with savannah nuances, there is also the Ijen Crater which presents the beauty of the crater on Mount Ijen, and the Gulf coast Green where the beach presents natural beauty with green seawater, and many other places. Content of 
photos and videos of natural beauty in the Banyuwangi region are grouped through the hashtag \#explorebanyuwangi

There are several Instagram accounts that can be said as loyal followers of \#explorebanyuwangi because the Instagram account is always posted using \#explorebanyuwangi in its caption. The Instagram account is an account created by Banyuwangi people whose posts have an interest in Banyuwangi especially travel and natural beauty, and photos and videos uploaded are reposted results from netizens posting using the hashtag \#explorebanyuwangi including an Instagram account @lovebanyuwangi @explore_banyuwangi @banyuwangi.id @wisatakabenciesbanyuwangi @wowbanyuwangi and others.

Anyone can use the hashtag \#explorebanyuwangi on his post on Instagram, as a result, many posts that do not match the content of \#explorebanyuwangi itself, such as posting personal merchandise but using the hashtag \#explorebanyuwangi there are also posting travel promotions and many more. where the hashtag \#explorebanyuwangi is a hashtag that aims to group travel content and natural beauty in the Banyuwangi area.

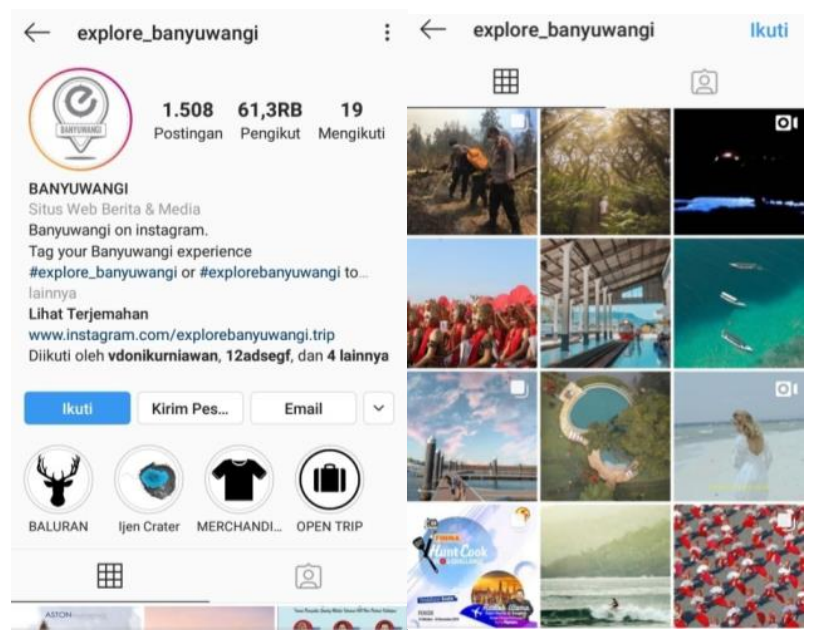

Picture 2. @explore_banyuwangi as seen on Instagram

The Instagram account @explorebanyuwangi is the Instagram account with the most followers than any other similar Instagram account, which is 61,300 followers with 1,508 posts to date. The content brought by the Instagram account @explore_banyuwangi is a photo of nuances of Banyuwangi's natural beauty taken from the repost of photos on \#explorebanyuwangi. Simply upload photos/videos to each Instagram account and include \#explorebanyuwangi then the Instagram account @explore_banywangi will repost according to what is appropriate for reposting. 


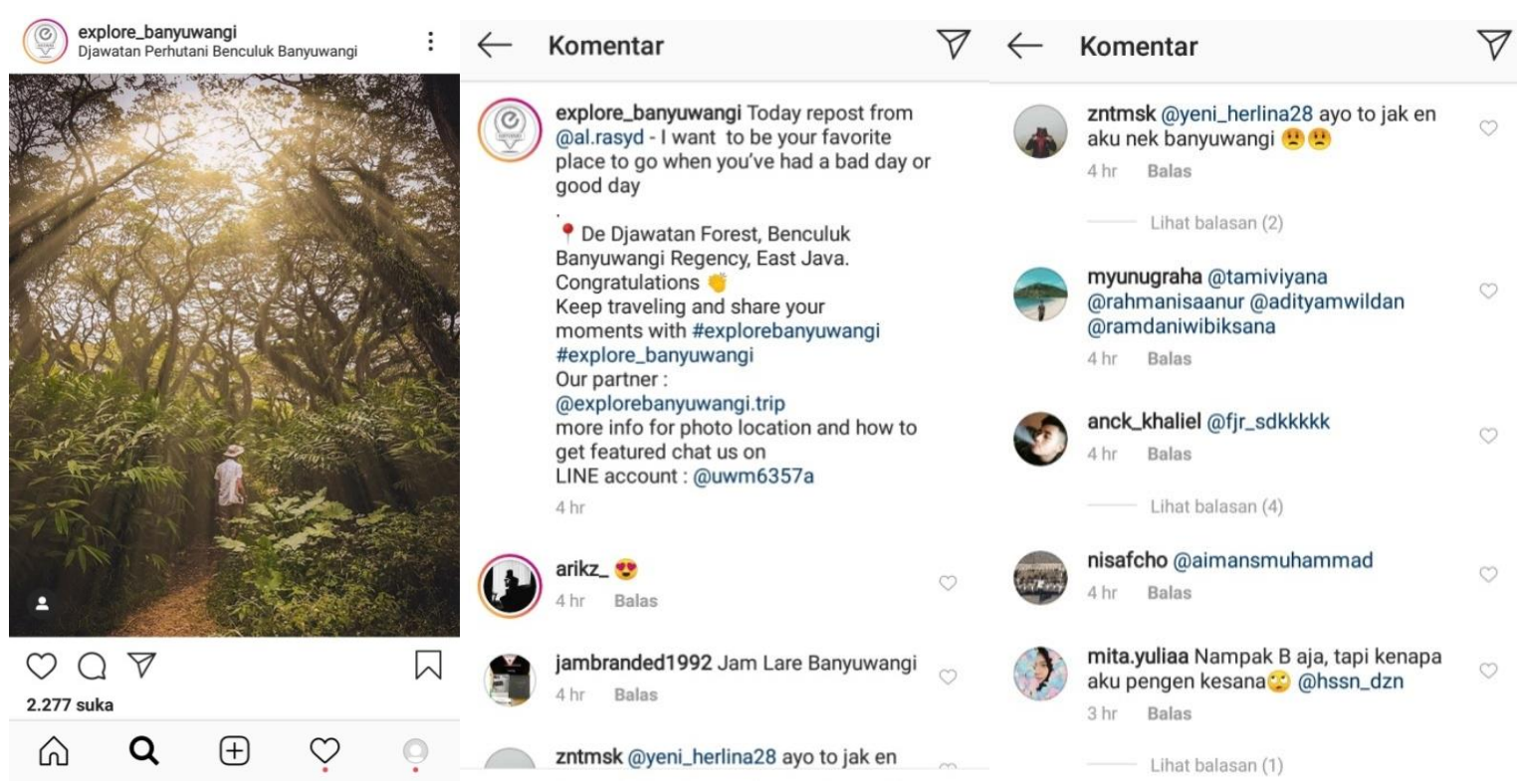

Picture 3. Post comment section \#explorebanyuwangi

In the post above managed to get a number of 2777 likes and 16 comments. Posts on the Instagram account @explore_banyuwangi are reposted from the Instagram account @ al.rasyid with the same caption and added information about the location and some hashtags. @explorebanyuwangi also gave information about the location in the photo post, namely Djawatan Perhutani Benculuk Banyuwangi, which if the location was clicked, would display several other Instagram account photos that also marked the location of Perhutani Benculuk Banyuwangi Djawatan.

Comments on these posts also mostly contain invitations from one user account to his friends by tagging the comment. Like the comment on the @zntmsk Instagram account that gives the comment "@yeni_herlin 28 let's go to my grandfather Banyuwangi" which in Indonesian "come take me to Banyuwangi"

And there are also comments from the Instagram account @myunugraha which only members comment "@tamviyana@ @rahmanisaanur @adityawildan @ ramdaniwibiksana" which means comments that tag their friends so that they all see the photo. @explore_banyuwangi also still invites other Instagram account users to share photos and stories about travel in Banyuwangi, and at the end of the caption @explore_banyuwangi also promotes@explorebanyuwangi.trip where the account is their travel service provider account.

Most of the concept photos in this account are the same, that is, a photo of a person with a background of a destination. This shows that the audience likes content with content like this: a destination view with elements of human interest. Moreover, Banyuwangi has a lot of spot adventure tourism spots, both water and land. The elements of human interest in these photos can cause a sense of desire of the public to visit the same place and take similar photos. Only a small number of photos in that account only show scenes without someone in them.

\section{\#Explorebanyuwangi's Profile On Instagram}

According to the millennial generation, the hashtag \#explorebanyuwangi is a place on Instagram social media to give and receive information about Banyuwangi. Many feel helped by the hashtag \#explorebanyuwangi, because most millennials today claim to seek information through social media first before visiting a place that has never been visited. Posts that are on 
\#explorebanyuwangi make other Instagram users have an overview of these tourist destinations.

Millennials who often consume information via the internet claim that both photo and video posts on \#explorebanyuwangi make it anxious to visit the natural attractions of Banyuwangi. Netizens who upload photos of natural destinations and use \#explorebanyuwangi indirectly carry out promotional activities to other Instagram users. Of course, this gave birth to several Instagram accounts that carry the theme of exploring Banyuwangi, showing the beauty of the destinations in Banyuwangi. From observations that have been made on several Instagram accounts with Banyuwangi city content, the top three accounts have the most followers

Table 1. Top 5 Instagram accounts about traveling in Banyuwangi

\begin{tabular}{|c|l|c|c|}
\hline no & \multicolumn{1}{|c|}{ Instagram account } & $\begin{array}{c}\text { Number of } \\
\text { Posts }\end{array}$ & $\begin{array}{c}\text { Number of } \\
\text { followers }\end{array}$ \\
\hline $\mathbf{1}$ & @ explore_banyuwangi & 1.508 & 61.300 \\
\hline $\mathbf{2}$ & @ banyuwangi.id & 304 & 24.800 \\
\hline $\mathbf{3}$ & @ wisatakabupatenbanyuwangi & 1.100 & 15.100 \\
\hline $\mathbf{4}$ & @ kotabanyuwangi & 183 & 5.234 \\
\hline $\mathbf{5}$ & @ lovebanyuwangi & 536 & 4.717 \\
\hline
\end{tabular}

@explorebanyuwangi has the most followers. Most of the contents of this Instagram account are reposted from photos of other people's accounts using the hashtag \#explorebanyuwangi, of course, their photos when in Banyuwangi. Followers of this account are the most because there are also Instagram accounts from other cities that use the words 'explore' like @exploresurabaya @exploremalang @explorebali @exploremedan @explorebandung and there are still many similar accounts from various regions in Indonesia.

Then there is the Instagram account @ banyuwangi.id which is the account with the second-highest number of followers after @explore_banyuwangi with a total of 24.800 followers, the great thing about this account is that the number of 24.800 followers can be obtained with only 304 posts. The content presented is actually not too different from @explore_banyuwangi but this account gives additional content, not only presenting tourist attractions in Banyuwangi, but this account also presents Banyuwangi cuisine, Banyuwangi customs, Banyuwangi figures/communities, to achievements that obtained by Banyuwangi district. But the posts on this account are still dominated by travel content.

@ wisatakabupatenbanyuwangi is the 3rd most Instagram account under @explore_banyuwangi and @ banyuwangi.id with 15,100 followers. As the name suggests, it is clear that this account focuses more on tourism content in Banyuwangi Regency. There is nothing special about this account because the content is actually almost the same as @explore_banyuwangi but this account presents more photos. Within one week, this account can upload 8 to 10 photos, while @explore_banyuwangi only uploads 5-7 photos per week. the number of posts is still more @explore_banyuwangi than @wisatakabupatenbanyuwangi because this account is younger than @explorebanyuwangi.

While the @kotabanyuwangi account is an account owned by the Banyuwangi government with a total of 5.234 followers who present information content about information about activities in Banyuwangi, such as announcements of events, events, and so on. In this account, the concept is very different from the other 4 accounts. Not a view and destination information, but rather provide information on activities and events that take place in 
Banyuwangi. It appears that the segmentation of this account leads to all circles, not specifically for travelers who are looking for tourist destinations in Banyuwangi.

In fifth place is @ lovebanyuwangi which has 4.717 followers. The differentiator of this account from other accounts lies in the structuring of Instagram feeds, where there are 3 columns whose posts have been segmented. It can be seen in the image below, where the left posting column is the result of reposting photos of netizens who use \#explorebanyuwangi, then the middle column that presents motivational words for their followers, and the right column which always presents events in Banyuwangi. This makes this account different from other accounts.

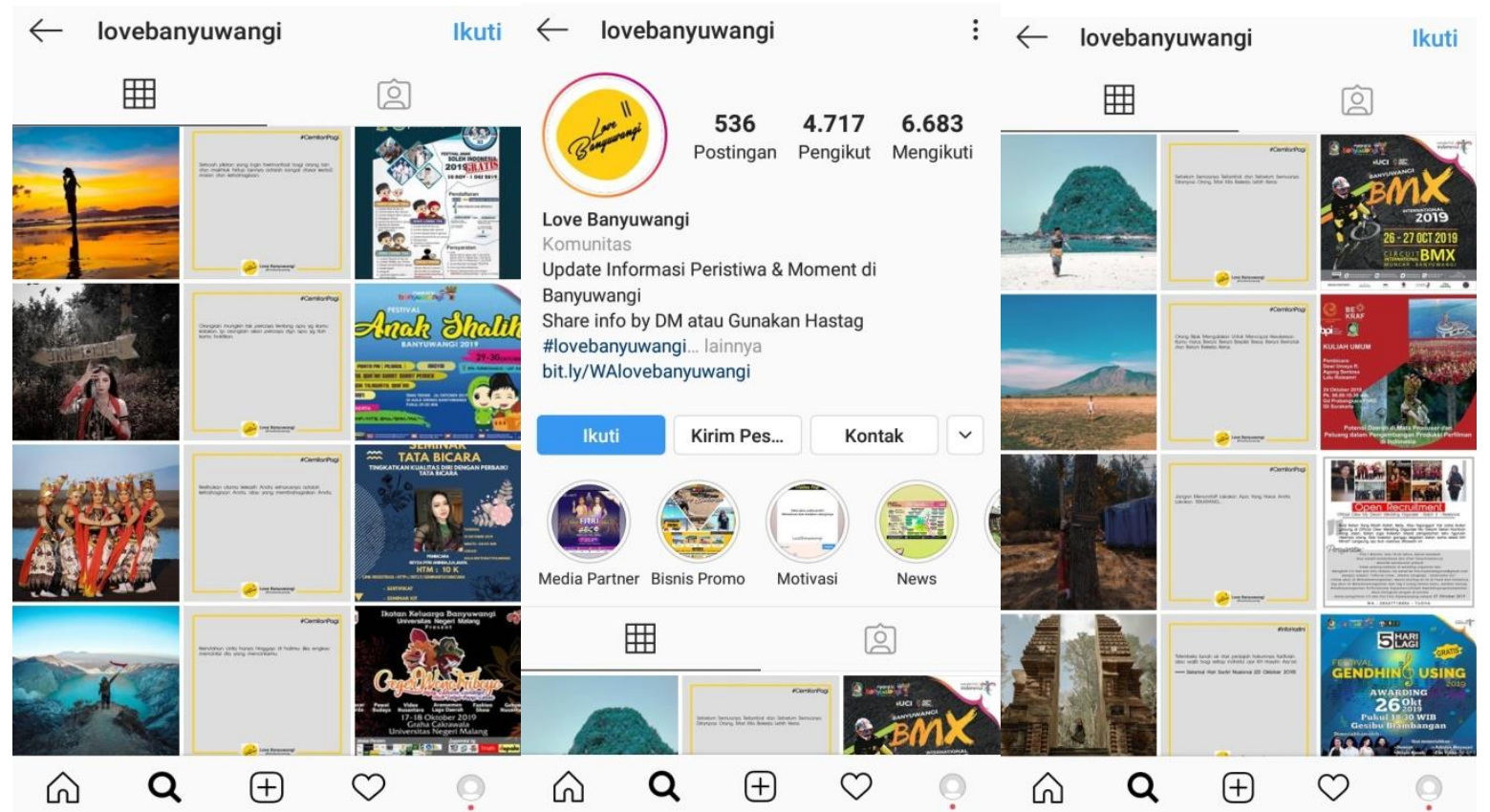

Picture 4. Another form of post layout on Instagram belongs to the account @ lovebanyuwangi

From an online survey, the author conducted, obtained data about the characteristics, patterns, usage, and effects of the promotion @explorebanyuwangi on Instagram. The data obtained is a partial portrait of how e-promotion @explorebanyuwangi.

Table 2. Characteristic Participant Using the Internet in Surabaya City in 2019

\begin{tabular}{lcc}
\hline Characteristics & n & \% \\
\hline Gender & & \\
$\quad$ Male & 74 & 40.2 \\
$\quad$ Female & 111 & 60.3 \\
\hline Age & & \\
13 - 15 year old & 5 & 2.7 \\
16 - 18 year old & 20 & 10.9 \\
19 - 21 year old & 144 & 78.3 \\
22 - 24 year old & 18 & 9.8 \\
\hline How often do you access the internet? & & \\
$\quad$ Every Day & 149 & 95.5 \\
Once every 2-3 days & 2 & 1.3 \\
Once every 4-6 days & 3 & 1.9 \\
Once every 2-3 week & 1 & 0.6 \\
Once a month & 5 & 3.2 \\
\hline
\end{tabular}




\begin{tabular}{lll}
\hline How long on average do you go online in a day? & & \\
Less than 30 minutes & 3 & 1.9 \\
1 hour & 8 & 5.1 \\
2-3 hour & 23 & 14.7 \\
3-4 hour & 15 & 9.6 \\
More than 4 hours & 112 & 71.8 \\
\hline With what devices do you access the internet? & & \\
Cellphone & 155 & 99.4 \\
Tablet & 6 & 3.8 \\
Laptop & 52 & 33.3 \\
\hline
\end{tabular}

From the above results the majority of respondents access the internet every day $(95.5 \%)$ using mobile devices $(99.4 \%)$. With an average duration of access of more than 4 hours a day $(71.8 \%)$.

Table 3. Preference of Millennial Generation in Surabaya in 2019 about \#ExploreBanyuwangi

\begin{tabular}{lll}
\hline Attitude and Behavioral Attributes & n & \% \\
\hline Which social media do you use the most? & & \\
$\quad$ Facebook & 14 & 14 \\
$\quad$ Instagram & 134 & 86.5 \\
$\quad$ Twitter & 14 & 27.1 \\
$\quad$ Whatsapp & & \\
\hline How often do you provide comments on various & & \\
types of social media accounts with the theme of & & \\
traveling such as Twitter, Facebook, Instagram, & & \\
and Website? & & 43.2 \\
$\quad$ Very rarely & 67 & 30.3 \\
$\quad$ Rarely & 47 & 24.5 \\
$\quad$ Neutral & 38 & 4.5 \\
$\quad$ Often & 7 & 1.9 \\
$\quad$ Very often & 3 & \\
\hline Your frequency level gives likes on traveling & & \\
themed posts uploaded on social media like & & 10.3 \\
Facebook, Instagram, etc.? & & 22.4 \\
$\quad$ Very rarely & 16 & 29.5 \\
$\quad$ Rarely & 35 & 27.6 \\
Neutral & 46 & 12.8 \\
Often & 43 & \\
Very often & 20 & \\
\hline
\end{tabular}

Instagram is the most used social media $(86.5 \%)$. Respondents more often give likes than give comments in a traveling-themed post.

Table 4. Preference of Millennial Generation in Surabaya in 2019 about \#ExploreBanyuwangi

\begin{tabular}{lll}
\hline Attitude and Behavioral Attribute & n & \% \\
\hline $\begin{array}{l}\text { You always access information about tourist } \\
\text { destinations through social media before }\end{array}$ & & \\
visiting the tourist destination? & & \\
$\quad$ Very rarely & 8 & 5.1 \\
Rarely & 17 & 10.9 \\
Neutral & 28 & 17.9 \\
Often & 74 & 47.4 \\
$\quad$ Very often & 33 & 21.2 \\
\hline
\end{tabular}




\begin{tabular}{|c|c|c|}
\hline \multicolumn{3}{|l|}{$\begin{array}{l}\text { How muc } \\
\text { seeing pos } \\
\text { accounts? }\end{array}$} \\
\hline Very low & 2 & 1.3 \\
\hline Low & 7 & 4.5 \\
\hline Neutral & 68 & 43.6 \\
\hline High & 64 & 41 \\
\hline Very High & 19 & 12.2 \\
\hline
\end{tabular}

In looking for travel-related information, respondents rely on social media before visiting a tourist destination. As many as $47 \%$ of respondents claimed to often seek information through social media. But only half of them were neutral in going on a tour after seeing a post about a tourist destination (43.6\%).

Table 5. Preference of Millennial Generation in Surabaya in 2019 against \#ExploreBanyuwangi

\begin{tabular}{lll}
\hline Attitude and Behavioral Attribute & n & \% \\
\hline $\begin{array}{l}\text { Are you interested in traveling? } \\
\text { Yes }\end{array}$ & 171 & 92.9 \\
No & 14 & 7.6 \\
\hline $\begin{array}{l}\text { Your main source of information about } \\
\text { traveling / tourism? }\end{array}$ & \\
$\quad$ Newspaper & 3 & 1.6 \\
TV / Radio & 20 & 10.9 \\
Social media & 163 & 88.6 \\
Family / Partners / Friends & 77 & 41.8 \\
Another source & 46 & 25 \\
\hline Have you ever been to a tourist attraction in & & \\
Banyuwangi? & & \\
Yes & 74 & 49.3 \\
No & 78 & 52 \\
\hline If Yes, please indicate which tour you & & \\
visited? (may be more than one) & & \\
Natural tourism & 71 & 55 \\
Culinary tour & 19 & 14.7 \\
Culture tour & 11 & 8.5 \\
Shopping tour & 9 & 7 \\
Never been to Banyuwangi & 53 & 41.1 \\
\hline
\end{tabular}

\begin{tabular}{lll}
\hline $\begin{array}{l}\text { How do you rate the ease of getting } \\
\text { information about \# explorebanyuwangi on } \\
\text { Instagram accounts? }\end{array}$ & \\
$\quad$ Very difficult & 2 & \\
$\quad$ Difficult & 2 & 1.3 \\
Neutral & 43 & 1.3 \\
Easy & 89 & 27.9 \\
$\quad$ Very Easy & 24 & 57.8 \\
\hline How much do you want to visit Banyuwangi & & \\
travel when you see \#explorebanyuwangi's & & \\
posts on other people's social media? & & \\
Very low & 2 & 1.3 \\
$\quad$ Low & 8 & 5.2 \\
$\quad$ Neutral & 74 & 48.1 \\
High & 62 & 40.3 \\
Very High & 15 & 9.7 \\
\hline
\end{tabular}




\begin{tabular}{lll}
\hline $\begin{array}{l}\text { People's posts about Banyuwangi tourist } \\
\text { destination make you have an idea about the } \\
\text { destination? }\end{array}$ & \\
$\quad$ Yes & 147 & 95.5 \\
$\quad$ No & 8 & 5.2 \\
\hline $\begin{array}{l}\text { What is the level of suitability of posts about } \\
\text { Banyuwangi tourism on social media with }\end{array}$ & \\
$\begin{array}{l}\text { reality? } \\
\quad \text { Very Not Suitable }\end{array}$ & 2 & \\
$\quad$ It is not in accordance with & 7 & 1.3 \\
$\quad$ Neutral & 96 & 4.6 \\
$\quad$ Suitable & 47 & 31.6 \\
$\quad$ Very suitable & 4 & 2.6 \\
\hline Will you capture it with photos / videos & & \\
when you travel to Banyuwangi? & 130 & 86.1 \\
$\quad$ Yes & 22 & 14.6 \\
$\quad$ No & & \\
\hline Will you post photos / videos of your visit to & & \\
Banyuwangi on your social media? & 119 & 86.9 \\
$\quad$ Yes & 14 & 10.2 \\
$\quad$ No & 7 & 5.1 \\
$\quad$ Not taking picture/video &
\end{tabular}

Millennial generation preference in the city of Surabaya shows that interest in traveling is very high $(92.9 \%)$. The main access to information sources for traveling comes from social media $(88.6 \%)$. Of the 74 respondents who claimed to have visited Banyuwangi, stated natural tourism $(55 \%)$ was their destination.

Millennials claim to easily get information about \#explorebanyuwangi (57.8\%). The level of desire of respondents is high (40.3\%) to visit Banyuwangi tourism after seeing \#explorebanyuwangi's post on other people's social media. Millennials will also post photos/videos of their visit to Banyuwangi on social media (86.9\%).

\section{CONCLUSION}

Instagram is the most used social media $(86.5 \%)$. Respondents more often give likes than give comments in a traveling-themed post. As many as $47 \%$ of respondents claimed to often seek information through social media. But only half of them were neutral in going on a tour after seeing a post about a tourist destination (43.6\%).

According to the millennial generation, the hashtag \#explorebanyuwangi is a forum on Instagram social media to give and receive information about Banyuwangi. Many feel helped by the hashtag \#explorebanyuwangi, because most millennials today claim to seek information through social media first before visiting a place that has never been visited. Posts that are on \#explorebanyuwangi make other Instagram users have an overview of these tourist destinations.

Content on \#explorebanyuwangi itself is more focused on the natural beauty of Banyuwangi, both the beaches, mountains, and plateaus, as well as the atmosphere of the city of Banyuwangi. Baluran National Park, Ijen Crater, Teluk Hijau, Pantai Merah, Djawatan Perhutani Benculuk Banyuwangi are some of the many attractions that appear on Instagram. The atmosphere of the city can still be said to be rare because Banyuwangi itself is more famous for its natural beauty.

Millennial generation preference in the city of Surabaya shows that interest in traveling is very high $(92.9 \%)$. The main access to information sources for traveling comes from social 
media (88.6\%). Of the 74 respondents who claimed to have visited Banyuwangi, stated natural tourism $(55 \%)$ was their destination.

Millennials claim to easily get information about \#explorebanyuwangi (57.8\%). The level of desire of respondents is high (40.3\%) to visit Banyuwangi tourism after seeing \#explorebanyuwangi's post on other people's social media. Millennials will also post photos/videos of their visit to Banyuwangi on social media (86.9\%).

\section{REFERENCES}

\section{Book}

Ester, Nina Parhusip \& I Nyoman Sukma Arida. 2018. Wisatawan Millennial Di Bali (Karakteristik, Motivasi, dan Makna Berwisata). Denpasar: Jurnal Destinasi Pariwisat Faiza, Arum, Sabila J. Firda, dkk. 2018. Arus Metamorfosa Millennial . Kendal: Achmad Jaya Group

Hudson, Simon. 2012. Sport and Adventure Tourism. New York: The Haworth Press, Inc.

Swarbrooke, John, Colin Bread, Suzanne Leckie, and Gill Pomfret. 2012. Adventure Tourism. New York: Routledge

\section{Internet}

Bappeda. Kabupaten Banyuwangi, Retrieved from http://bappeda.jatimprov.go.id/bappeda/ wp-content/uploads/potensi-kab-kota-2013/kab-banyuwangi-2013.pdf, 25 September 2019

Christiany Juditha, Josep J. Darmawan. Penggunaan Media Digital dan Partisipasi Politik Generasi Millennial, Retrieved from https://media.neliti.com/media/publications/272787none-be596b32.pdf, 26 September 2019 http://library.binus.ac.id/eColls/eThesisdoc/Bab1/ BAB\%20I-TS-R-2018-0049.pdf

Yanuar Surya Putra. Theoritical Review: Teori Perbedaan Generasi, Retrieved from http://jurnal.stieama.ac.id/index.php/ama/article/viewFile/142/133, 26 September 2019 